\title{
Pathologies of Development Practice: Higher Order Obstacles to Governance Reform in the Pakistani Electrical Power Sector
}

Abstract

Development actors are regularly aware of the shortcomings of governance interventions before, during, and after development assistance is introduced, yet those programs continue and are even revisited. Why? This paper uses the Pakistani experience with power sector reforms to illustrate how the donor-led reform agenda had readily apparent shortcomings. A new wave of development thinking responds to such failures by drawing on complexity theory and moving toward more local, iterative and experimental approaches. However, by highlighting how the awareness of problems with reforms isn't sufficient to avoid them, this paper points to a higher order of obstacles which remain unaddressed.

\section{Introduction}

Development actors are regularly aware of the shortcomings of governance interventions before, during, and after development assistance is introduced, yet those programs continue and are even revisited. Why? Why doesn't the awareness of the problems with development interventions prevent the continuation of failures, the repetition of mistakes, or more caution in essaying grand plans for institutional reform? This paper uses the history of reforms in the Pakistani power sector to illustrate this puzzle and to suggest some partial answers which link the content of reforms (and the poor outcomes) to the structures of development assistance which drive them.

The major focus of this paper is to show how there are repeated points in Pakistan's experience with power sector reforms where the challenges and shortcomings are noted but not acted upon. The experience of failure didn't change approaches to reform despite abundant feedback channels and high level political support. That development assistance generally - and governance reforms in particular - 
produce poor results is old news, but this nuance in the path to disappointment is usually overlooked in the literature. What the Pakistani power sector case shows is that key participants had well founded reservations about the reforms. In the run up to the 1994 power policy which invited the establishment of independent power generation facilities (Independent Power Producers, or IPPs), the preparatory work by consultants and government strategists clearly identified a necessary sequence of steps to ensure that private investment would be received by institutional arrangements conducive to it. When the preconditions weren't met, the major goal of the reforms (to have investment without sovereign guarantees) was lost. The World Bank's analysis of its own role reveals the multiple ways in which the intervention's shortcomings were visible at early stages. In the more recent plan outlined by the Friends of Democratic Pakistan (FODP) and the programming of the United States Agency for International Development (USAID), development actors have returned to the same agenda - with thus far similar results.

The fact that development projects aren't effective or that governance interventions go wrong is well-trodden ground. Pritchett et al. (2013) castigate these programs for their pursuit of 'development as accelerated modernization' - in which non-local expertise sets the agenda - and show how such reforms are undone by isomorphic mimicry and premature loading. Both a superficial copying of foreign institutions as camouflage (isomorphic mimicry) and then stressing them with challenging reforms (premature loading) are present in the Pakistani case and helpfully explain why the reforms have disappointed.

A new wave of development thinking advocates more systemic and complex conceptualizations of development challenges (Ramalingam, 2013). Based on this improved conceptualization of development challenges, the approaches recommended in this new wave are iterative, adaptive, and politically aware (Andrews, 2013; Booth \& Unsworth, 2014). While there is sound reasoning behind this approach, its viability is challenged when we consider that past development efforts have been aware of 
their shortcomings but unable to correct their path. Moreover, this paper will argue that the content of governance reforms is linked to the structure of development assistance, thus revealing a higher order of obstacles to successful governance reform.

The case of the Pakistani power sector reforms could be treated as important because Pakistan has the world's sixth largest population, or because it received the second-most USAID and most UK Department for International Development (DFID) assistance in 2013. Pakistan's experience with electricity sector reforms in the 1990s was common to many others, both in terms of the design and execution of the reforms as well as the outcomes, and there are general lessons to be learnt about development assistance from this case. Lastly this is a site of ongoing and substantial donor involvement from the World Bank and USAID programs in the 1980s and 1990s, many programs of the Asian Development Bank throughout, and - particularly since the Kerry-Lugar-Berman bill of 2009 - huge involvement by USAID which approaches $\$ 500$ million for the energy sector alone between $2010-2014$. Most recently, the proposed Chinese investment in the Pakistani power sector of over $\$ 30$ billion has raised the profile of international involvement in the sector yet further.

Following this introduction, this paper identifies the current arguments in development thinking which are influencing major development actors to adopt more adaptive approaches to development in light of a more complex framing of development challenges. The third section of this paper explores the case of the Pakistani power sector with particular attention to the way in which the shortcomings of reforms were considered, but the development actors didn't change their course. The fourth section seeks to understand why development interventions weren't adapted in the face of this knowledge, and how the structure of the intervention contributed to that lack of adaptation. The fifth section briefly concludes. 


\section{Towards A More Complex Approach to Development}

Governance reforms that concentrated on formal rules and excluded the informal realities of country context have largely failed (Disch, Vigeland, \& Sundet, 2009; World Bank, 2008). OECD

development aid targeting governance as a set of formal rules has had 'limited impact' despite spending in excess of $\$ 10$ billion per year:

'Programmes to improve the investment climate, strengthen the rule of law, or fight corruption do not fail just for lack of ownership or attention to politics. They fail because they make the wrong starting assumption: that progressive change consists in, and can be achieved through, strengthening formal, rules-based institutions that reflect a clear division between public and private spheres of life.'

(Institute of Development Studies, 2010)

Pritchett et al. (2013) explain the widespread failure of governance reform that seeks to change

institutions using two explanatory mechanisms: isomorphic mimicry; and premature loading. Isomorphic mimicry refers to the superficial adoption of organizational forms as camouflage so that a donor recipient can 'look like a state' while continuing with its existing practices. Isomorphic mimicry blends three sources of isomorphism identified in the sociology of organizations (DiMaggio \& Powell, 1983), which are coercive (driven by concerns of power and legitimacy), mimetic (a response to uncertainty by modelling the forms of other organizations which are perceived as legitimate and successful), and normative (through increasing professionalization). All three are found in development, but - while Pritchett et al. blend them for the purposes of their argument - drawing a distinction between them allows for the recognition that mimicry can be a very successful strategy in an evolutionary framework, and that the damage happens under conditions where a weak and fragmented state is pressured into adopting certain organizational forms (Krause, 2013). Preserving necessary operational practices while adopting formal structures as legitimating myth or ceremony is a classic decoupling strategy (Meyer \& Rowan, 1977) for seeking external approval without upsetting local stakeholders.

Premature loading is a related idea in that the work of the organization doesn't yet fulfil its written or formal description (which may be the result of relatively recent institutional reforms). Thus, 
when a burden of fulfilling the obligations of its form is put on this newly reformed organization, and it can't meet that challenge, the stress of this burden on the organization before it is mature contributes to the failure of the governance reform. With both isomorphic mimicry and premature loading, the key concept is that the external form of the organization does not match how it works in practice.

Isomorphic mimicry and premature loading result from the practice of 'development as accelerated modernization' (Lant Pritchett et al., 2013) . In this reading, development assistance seeks to 'skip to Weber' by copying the institutions of the Global North without going through the extended power struggles which produced those institutions. The essence of development assistance is thus decontextualized knowledge to be applied outside the time and space in which it was first acquired. A new wave of development thinking seeks to respond to these critiques of development assistance by conceiving new ways to approach development. One prominent line of thought is that of Andrews (2013), who proposes Problem Driven Iterative Adaptation (PDIA). PDIA departs from traditional development assistance by looking from the outset to try multiple experimental approaches which allow development actors to learn from mistakes. Rather than a sequential series of reforms charting a path to a donor-determined set of institutions (an idealised Denmark or New Zealand (L. Pritchett \& Woolcock, 2004), reforms are approached by trying out what works within a specific context. In an alternative framing of a related approach, Booth and Unsworth (2014) argue for 'locally led' and 'politically smart' development assistance which puts a premium on the depth of local experience and political sensitivity of the personnel deployed by development actors.

Closely related insights for development have been generated by understanding development challenges in terms of complex adaptive systems (Ramalingam 2013). In a complex adaptive system, agents learn from and change in response to the system they exist in (Axelrod, 1997; Miller \& Page, 2007). These agents interact with each other in unforeseen ways, triggering negative and positive feedback loops (Arthur, 1990; Jervis, 1997) which can produce emergent outcomes which weren't 
necessarily foreseeable beforehand. The path from agent interactions to emergent outcomes of interest in a complex adaptive system is non-linear and thus ill-suited to the types of linear causal models which underlies the power sector reform programs of the 1990s: you cannot depend on input $x$ to produce output y (Mitchell, 2009). Complex adaptive systems are also highly context sensitive, and differing starting conditions will produce varying adaption responses from agents just as they adapt to stimuli such as reforms (Holland, 1992). Importing reform strategies from different settings would then need to be undertaken with extreme caution.

Two important development actors - DFID and USAID - have begun to incorporate the lessons of complexity and more systemic conceptualizations of development into their operations. USAID published 'Local Systems: A Framework for Supporting Sustained Development' in which a more systemic perspective is taken on working with multiple and interconnected local actors to achieving lasting results (United States Agency for International Development, 2014). DFID undertook an end-toend Review of Programme Management in 2013-14 that sought to draw on some of the lessons of complexity and involved Ben Ramalingam, the author of Aid on the Edge of Chaos (Ramalingam, 2013).

Complexity offers a broader set of insights for public policy beyond the special case of developing countries which follow from the distinctive framing of the problem based on principles of complexity: agents will adapt to policies and affect one another; cause and effect will only be known in hindsight; and starting conditions can be replicated, but not end states (Colander \& Kupers, 2014). However, not all problems are complex - seeing complexity everywhere is as much a failing as failing to see it at all. In a simple system one can follow a recipe, and in a complicated system solutions can be engineered (Kurtz \& Snowden, 2003).

While the language and concepts of complexity add something to discussions of development, there is a real danger of putting old wine in new bottles. The insight that reform strategies shouldn't be introduced from other settings without consideration of the local context is a development 
commonplace which is present in every primer on development written in the last 20-30 years. It is perhaps the first lesson that every veteran of the field would impart to a newcomer. And yet why does it seem so hard to avoid? Why is it that this fundamental tenet of development thinking was not reflected in the push for electricity sector reform?

In the next section this paper proceeds to apply the critiques of isomorphic mimicry and premature loading to the experience of governance reforms in the Pakistani power sector from the 1990s through the present day. While the authors cited in section 2 might agree with the application of their critiques to this specific case, neither they nor I are suggesting that the adaptive and experimental approaches to development which have evolved out of those critiques could be simplistically applied to the Pakistani power sector. Advocates of experimental and iterative approaches to development assistance want to depart from large-scale institutional reform efforts and would not advocate reforms such as those of the Pakistani power sector in the mid-1990s. The new wave of development approaches which build on the Pritchett et al. (2013) critique - such as PDIA (Andrews, 2013) and politically smart and locally led (Booth \& Unsworth, 2014) - are not intended to function at that scale. Rather than propose to solve the problems of the Pakistani power sector, the goal of this paper is to use the lessons of Pakistan's experience with power sector reform to reveal a higher order set of obstacles to governance reform produced through the pathologies of development practice discussed in the fourth section of this paper.

\section{Institutional Reforms in the Pakistani Power Sector}

The introduction of IPPs in Pakistan followed the World Bank's blueprint for electricity sector reform, and - as one of the first such efforts - the tools of this reform (such as power purchase agreements) developed in Pakistan were used in other countries where IPPs were introduced. The Pakistani power sector is a key part of the propagation of a standardized set of reforms for the electrical 
power sector which were pushed to developing countries by the World Bank and its allied bilateral and multilateral donors. Neither the view that Pakistan was part of this standardized reform push, nor the difficulties faced by such reforms where they were implemented, are contentious readings of history. Premature loading and isomorphic mimicry are both present here. What I seek to show here is that the reforms themselves were challenged and questioned before, during, and after they were introduced.

The World Bank and USAID provided the leadership for power sector reform in Pakistan in the early 1990s through their championing of the mammoth Hub River Company (Hubco) private power generation plant and establishment of the basic strategy for power sector reforms in Pakistan respectively. WAPDA's Strategic Plan for the Privatization of the Pakistan Power Sector prepared by a USAID contractor in 1992 for the Water and Power Development Authority, the vertically-integrated electrical utility, is much more than a caricatured import of Washington consensus principles despite being built around them. The central tenet is to 'provid[e] for the greatest possible role for the private sector and the movement over time towards full competition.' This approach is proposed as the solution to three 'critical goals' of the Government of Pakistan:

A. Enhance Capital Formation for the Pakistani Power Sector (PPS) outside the Government of Pakistan (GOP) Budget and without Sovereign Guarantees;

B. Improve the Efficiency of the PPS through Competition, Accountability, Managerial Autonomy, and Profit Incentives; and C. Rationalize Prices and Social Subsidies, while Maintaining Certain Socially Desirable Policies such as Rural electrification and low Income 'lifeline' Rates.

(International Resources Group, Putnam Hayes \& Bartlett, \& Hunton \& Williams, 1992, p. i) The 1992 strategy doesn't go into a lot of detail as to why or how private management will necessarily do a better job than public sector management. This reasoning is addressed to some extent under goal B, but the construction of this critical goal contains both a goal (efficiency, albeit undefined) and a chosen approach - private management. The long-term viability of public sector management is not considered, though the conditions and sequencing of reforms which can provide the setting for the success of private management are discussed. 
The principal prerequisite for the privatization strategy is the corporatization of WAPDA: its reorganization into discrete profit centres with independent management and separate accounts. Once these corporatized sub-divisions establish a commercial track record, then they will be 'ripe for privatization' (International Resources Group et al., 1992). Further:

'The introduction of profit incentives and competition, if properly implemented, will ultimately improve the efficiency of the PPS. These improvements cannot be achieved, however, without fundamental changes in the PPS and the promotion of a business, regulatory, and political climate conducive to private investment.' (International Resources Group et al., 1992, pp. 4-1) This sequencing puts the entire burden of reform on WAPDA and the Government of Pakistan. For WAPDA to reorganize itself and secure its commercially viability before privatization means that the hard work of ensuring timely and complete bill payments, eliminating political interference, and balancing costs and revenues will be substantially completed. Additionally, for the Pakistani state to successfully promote a business, regulatory, and political climate suitable for private investment would be a tremendous achievement at a time of political turmoil and economic uncertainty. For privatization to be undertaken after these achievements by WAPDA and the broader state suggests that the authors have limited hope for privatization to address the fundamental problems underlying poor power sector performance.

The authors of the 1992 strategy understood the limits of private sector management and were cognizant of the preconditions for the private sector to offer any advances over the public sector.

'The PPS whether privatized or not, will be able to raise private, non-guaranteed, nonconcessionary financing at 'reasonable' cost only when private investors have confidence in the entities and environment in which they are investing. This will require enforceable contracts for power sales and fuel purchases, predictable and fair regulation, and a stable social and political environment. This situation does not now exist in Pakistan.' (International Resources Group et al., 1992, pp. 2-2)

Despite their entirely valid reservations, the authors of the 1992 strategy still put out a relatively aggressive timetable to achieve decentralization, corporatization and selected privatization by 1994 , with full operation of the private and competitive Pakistan power sector from 1996 onwards. 
In order for the 1992 strategic plan to become reality it needed to be worked into specific policy prescriptions. In October 1993, shortly after taking office, Prime Minister Benazir Bhutto constituted a twelve member task force to:

'draw up a co-ordinated and comprehensive Energy Policy, formulating strategies for the elimination of load shedding, recommending proposals for mobilization of resources and promoting private sector investment, and making recommendations for enhancing indigenous oil and gas production.' (Government of Pakistan, 1994)

The Prime Minister gave a deadline of six weeks to complete the report. Twenty-three additional members were drafted to provide specialist knowledge. The committee was headed by the Prime Minister's Special Assistant for Economic Affairs and included the highest ranked bureaucrats in the power sector as well as prominent industrialists in a manner suggestive of an embedded bureaucracy (Evans, 1995). The virtues of the Report of Prime Minister's Task Force on Energy become most apparent when contrasted with the 1994 policy which was ostensibly based on it.

There are major differences between the task force report and the 1994 policy in terms of the amount of new capacity to be added and the manner in which projects are to be identified. The task force report called for $1500 \mathrm{MW}$ by 1998, and the policy itself anticipates about $1500 \mathrm{MW}$ of new projects, but the 1994 policy set no limits on the new capacity. More serious, though, is that the 1994 policy was based on receiving unsolicited bids at a pre-determined price.

The proposals may have been for private sector investment, but there was no price competition involved because the price was fixed in the policy. The generosity of the terms can be gauged by the massive investor response; almost 30,000 MW worth of proposals (Private Power and Infrastructure Board, 2001), $2000 \%$ of what the task force report required. Competition on price typically involves a pre-identified project to be prepared for bidders who compete on price and other technical criteria. While such solicited bids were envisioned in the task force report, and competition is central to the efficiency gains envisioned in the 1992 strategic plan, the 1994 policy did not adopt that approach and never attempted to introduce price based competition into the power generation market. 
A second manner in which the 1994 policy failed the goals of the 1992 strategic plan was in that it involved sovereign guarantees for private investors. The logic behind a sovereign guarantee for private investors is that it mitigates the risk of the investment by forcing the Government of Pakistan to back the stream of payments from the power sector. A World Bank assessment concluded that 'It is doubtful whether any IPPs could have been financed in Pakistan without government guarantees since perceptions of Pakistan's risk had limited financing to terms of 18-36 months' (Fraser, 2005). Pakistan has regularly owed substantial payments to the IPPs and even committed a sovereign default due to non-payment in 2012 (Kiani, 2014; Rana, 2012).

International financial institutions played an integral role in financing the IPPs set up under the 1994 policy. Eleven of the Sixteen IPPs set up under the 1994 policy (88\% of the total MW, and thus close to the same percentage of total investment) received funding from the World Bank group, and $85 \%$ of the foreign debt was from official sources (Fraser, 2005). The foreign debt was repayable in 10 years on average and backed by the Government of Pakistan's sovereign guarantee. As the primary financiers of Pakistan's IPPs, it is the World Bank and other international financial institutions whose risk perceptions were being mitigated by Pakistan's sovereign guarantees. The debt with which $80 \%$ of the $\$ 5.3$ billion total IPP investment was undertaken was owned by private investors despite the Government of Pakistan's guarantee. Pakistani consumers paid for that debt within (on average) ten years of the plants achieving commercial operations, but ownership remained with private investors. The investments were considered untenable without sovereign guarantees, but at the same time the international financial institutions would not countenance lending the money to the Government of Pakistan itself.

The reorganization and corporatization of WAPDA was the focus of a later report entitled Report of the Committee Constituted by the Ministry of Water and Power for Corporatization of WAPDA (Power Wing), dated October $3^{\text {rd }} 1997$ (Ministry of Water and Power, 1997). One of the authors, Mian Shahid 
Ahmad, also worked for the USAID contractor preparing the 1992 strategy paper. There is a clear continuity between the 1992 strategy and the 1997 report; the later report is primarily concerned with one objective within the framework laid out by the 1992 strategy. The timetable in the 1997 plan - less aggressive than in the 1992 strategy - is for corporatization within two years and a competitive market within 5 years after corporatization. No mention is made of the intervening five years when no progress on these same goals was made, though there is a warning regarding the need to follow through on the government's commitments: 'The committee [of authors] wishes to stress that unfaithful or halfhearted implementation will not yield the expected results, and consequently, the Policy and the very concept of corporatization and privatization will stand discredited.' Although the distribution companies were reorganized into discrete entities in 1998, the requirements identified as necessary precursors to corporatization and privatization were never fulfilled.

The 1992 strategy and 1997 report both acknowledge that they are asking for a sea change in the principles of operation, but say little or nothing to address how that change will be achieved. The 1997 report recognizes that currently, 'most of the managerial decisions involve social and political considerations' yet it offers nothing regarding the transition from the status quo to a position where the 'primary focus of each corporate entity will be profit' (Ministry of Water and Power, 1997, p. 11). Executive fiat alone, it would seem, was supposed to accomplish this transformation. Corporatization never happened, and the social subsidies and flawed hiring practices of the electrical utilities still make news today.

The 1992 USAID privatization strategy deserves credit for not blindly celebrating all private power schemes. In particular, they note the inappropriate 'use of imported oil at Hub River over imported coal or domestic fuels.' The USAID privatization strategy also had misgivings about the role of sovereign guarantees:

'Currently, new generating capacity being developed by private interests, such as the Hub River project, are receiving such substantial GOP and World Bank guarantees and underwritings that 
they do not represent good examples of private investment.' (International Resources Group et al., 1992, pp. 3-6)

The Hubco project went ahead despite this stated opposition in one of the key policy documents of Pakistan's unbundling and privatization.

Behind the scenes of the international actors promoting a private sector agenda for developing country power sectors were other cautionary voices as well. At a roundtable between Electricité de France and the World Bank (World Bank, 1993), several reservations were voiced by French participants. Notably, they did not see any plan to achieve the desired separation of utility management from the political establishment. Instead, they saw a generic plan and no requirement for specific analysis on a case by case basis, and they feared that the functioning of an efficient regulatory agency would require an 'institutional maturity and a balance of power which is not necessarily the prerogative of developing countries.' The French commentary also included a regret that the notion of public service had been discarded in this reform agenda - which can be read in terms of the differing social construction of economic rationality between France and the United States (Dobbin, 1994). In general, the roundtable participants recognized that complex institutional transformation such as the deregulation and privatization of the power sector in a developing country would be hampered by deficiencies in administrative capacity, and that few examples of such reforms existed to draw upon. Similarly, a discussion paper at the World Bank Group (Glen, 1992) concluded that inducting private capital under sovereign guarantees can defeat the initial goals of adding to the investment in a country.

USAID funded technical assistance for privatization and unbundling ended in 1994 per the Pressler amendment which disallowed aid to countries developing nuclear weapons. With the departure of USAID and its consultants the Government of Pakistan lost access to a lot of the expertise it had relied on in developing the 1994 Power Policy. Several of the clearly written provisions of the policy were bypassed in the course of the induction of IPPs. Mian Shahid Ahmed believes that he and the team of USAID contractors could have shaped a better policy had they remained in place. 'While the scepticism 
expressed in the 1992 strategy towards Hubco supports that view, he never had the opportunity to influence the response to the 1994 policy as USAID's involvement ended in 1994 subsequent to the Pressler Amendment.

The World Bank's involvement with Hubco failed to meet its own standards. The implementation completion report (World Bank, 2001) declared the outcome to be unsatisfactory, the World Bank's performance to be unsatisfactory, the Government of Pakistan's performance to be unsatisfactory, that the framework established for IPPs was unsustainable, and that there was negligible contribution to institutional development.

In its assessment, the World Bank notes that lending to Hubco consumed the entirety of the Private Sector Energy Development Project, one of two World Bank vehicles for private sector energy development in Pakistan, and that the project was perhaps too big as the initial IPP in Pakistan. The World Bank report notes that 'High level senior management attention may have led to inadequate attention being given to dissenting views during the review process' (World Bank, 2001, p. 18). The scale of the World Bank's commitment to Hubco led to it becoming a broker in resolving issues between the Government of Pakistan and Hubco. The World Bank's 'involvement went far beyond what was prudent for a development banker and exposed the Bank to conflicts of interest and reputational risk' (World Bank, 2001, p. 18).

The most grievous shortcoming of the Hubco project is visible in the period 2001-2006 when economic dispatch was implemented at the National Power Control Centre. The job of the National Power Control Centre is to organize and manage the generation of power so that demand is met. Economic dispatch is the process of prioritizing power generation plants in order of their variable costs and then using them in that order. When economic dispatch principles were used from 2001-2006 Hubco's energy production declined from 7168 GWh in $2000-01$ to a low of 1648 in $2003-04$, or $23 \%$ of 
its 2000-01 production, because it made no sense to run this expensive power plant ahead of cheaper alternatives (Rifai, 2009).

While Hubco was uneconomical relative to other power plants (public and private), the entire IPP program was set up to be a loss-making proposition for Pakistan. The World Bank states that 'the issue whereby WAPDA would lose implicitly US $\$ 4.1 / \mathrm{kwh}$ bought from IPPs was acknowledged but not addressed through the loan' (World Bank, 2001). The breakdown of the loss is that the IPPs would be paid US $\$ 6.5 / \mathrm{kwh}$ by WAPDA, $24.2 \%$ of units would be lost in getting those units to consumers (transmission and distribution), meaning that WAPDA's cost per unit served to a consumer was effectively US $\$ 8.6 / \mathrm{kwh}$ while the average revenue in 1994 was US $\$ 4.5 / \mathrm{kwh}$. The World Bank review describes it as 'highly unlikely that the tariff increases of this magnitude would have been politically or socially acceptable, or even commercially sustainable' (World Bank, 2001, p. 18).

Neither the Government of Pakistan nor the World Bank managed to keep the IPP program under control. The World Bank and other lenders were paid back in 10 years, but the consequences of unaffordable power based on expensive imported fuels are very much still with Pakistan. The introduction of IPPs into Pakistan was isomorphic with the standard paradigm, but (the arguable case of Hubco aside) it wasn't coercive; Pakistani political and administrative leaders played a willing role. The basic parameters of the privatization policy, however, were shaped outside Pakistan and without respect to its institutional capacities.

Most experiences with the standard paradigm for electricity sector reform ended poorly (Williams \& Ghanadan, 2006). Twenty-one of thirty-four private power projects starting in the 1990 s renegotiated their central agreements with the host government by 2005 (Woodhouse, 2006, p. 173). In India, the focus on expansion of generation capacity through IPPs was misplaced in a context of decaying infrastructure and mismanagement of distribution (Kale, 2004). Generous terms for IPPs across Asia attracted investments which weren't financially viable (Williams \& Dubash, 2004) and put the 
burden of risk for private investments on national governments (Wells \& Ahmad, 2007). In many countries where these reforms were tried, the reforms were undone by the underlying political economy of the power sector, the exigencies of the state's fiscal needs, and patronage politics (Victor \& Heller, 2007).

The reform program implemented in Pakistan in the 1990s falls squarely in line with this standard paradigm, both in terms of the approach and the disappointing outcomes. The example of the introduction of IPPs as part of a move towards a competitive market for electricity shows how policy departed from its lofty concepts, how prerequisites for reform were abandoned or ignored, and the nascent regulatory structure could not manage the influx of capital on the scent of large profits.

The FODP report (Friends of Democratic Pakistan, 2010) describes energy sector governance as fragmented and says that the 'disequilibrium' and 'disharmony' generated by this fragmentation undermines the achievement of energy security. The solution proposed is an integrated energy sector in which water, power, oil and gas are not planned and regulated separately. A single ministry of energy which will combine the existing Ministry of Water and Power and Ministry of Petroleum and Natural Resources is the key objective. Further, the two regulatory authorities for power and oil and gas must be merged. As an immediate measure, a senior energy adviser position on the staff of the Prime Minister will monitor and push through the implementation of energy sector actions such as those laid out in the FODP plan. The report also observes that 'Public sector energy companies (PSECS) should be run on good corporate governance models and have a commercial orientation with incentives for improved performance.'

The disengagement with Pakistan's politics and what Pakistan's rulers want is exemplified by the position of senior energy adviser proposed in the FODP report. The senior energy adviser was to report directly to the Prime Minister - above the relevant ministers, in effect - and would be empowered to drive through reforms. The designers of the FODP program intended to solve the implementation 
problem that previous reform programs had struggled with by effectively bypassing the politicians (there was to be no 'blank check'). ${ }^{i i}$ No senior energy adviser post with these powers was created. Although the members of the FODP - including representatives of the Pakistani government - met in Brussels in October 2010 and issued a joint communiqué introducing the energy plan (Friends of Democratic Pakistan 2010b) among other items, the Pakistani Minister of State for Foreign Affairs declined the additional aid because it would not allow decision making regarding the spending of that aid to rest outside the Pakistani government ("Govt agencies to manage flood aid, donors told," 2010).

The FODP approach had significant signs of a more coercive form of isomorphism. In particular, the attempt to introduce an advisory position to control the reforms (to be filled by an FODP-approved person) was a blatant attempt to push through an externally driven agenda over local political resistance. The Pakistani response was to allow the report to proceed without actively participating in it, and then to withdraw its support. Despite the resistance of the Pakistani government to the FODP report, various FODP members continued to fund development projects in the Pakistani energy sector which sought to achieve the same objectives identified in the FODP report.

As a USAID contractor placed at the Ministry of Water and Power as part of the Energy Policy Project, I found little scope there for a critical perspective when the definition of the problem and its solution are dictated by the funding agency. For example, in USAID's terms of reference for a key power sector reform project, the goals include the elimination of subsidies and the adoption of a 'commercial' rationality for the state owned distribution companies (United States Agency for International Development, 2010). Any contractor engaged in this program is legally bound to work towards the achievement of these goals, irrespective of what they might consider the merits of imposing a commercial rationality on a public sector organization providing a vital state service. The terms of the project contract constrain development practitioners to those terms, bind them to evaluation on those same terms, and serve as the basis for selecting among contractor proposals. The morbidity of 
governance reform in the Pakistani electricity sector has its origins in the development practices through which those reforms have been approached.

\section{Pathologies of Development Practice}

The painfully circular experiences of reforms in the Pakistani power sector shed light on three different approaches to reform. Each of these approaches is undone by the pathologies of development practice - the tools of development assistance themselves. The first approach, the standard one, is the tried and trusted-to-fail approach of big development which hammers at a predetermined set of objectives. This standard approach is undone by isomorphic mimicry and premature loading. The second approach appears only peripherally in that it represents a path towards a focus on public service excellence which was not taken. Implicit in the comments of Electricité de France on prospective World Bank electricity sector reforms is a treatment of public service which is quite distinct from the new public management inspired approaches pushed through international development. The third approach is the newest one, informed by past governance reform failures and drawing on complexity. The prospects for each of these approaches to reform can be informed by the preceding section which details how the Pakistani power sector reforms of the 1990s were launched on an aggressive timetable for corporatizing and commercializing the public sector as a precursor to enticing private investment. The previous section describes how this history shows isomorphic mimicry and premature loading in action. The power sector took on the external forms required by the donor-driven programs while the local political economy that shaped power sector operations remained intact. The preconditions for private investment were skipped and the resultant investments were adjudged by the donors to have had no institutional impact. This history of repeated failures at institutional reforms exposes the contribution of the intrinsic characteristics of the instruments of development assistance themselves. 
These instruments and their inherent characteristics influence each of the three approaches to reform by limiting the pathways of possible action.

Although many critiques of the standard approach to development are available, this paper has primarily used Pritchett et al.'s (2013) succinct and trenchant summation of decades of counternarrative. Albert Hirschman was amongst the earliest critics of grand theories of development such as modernization theory. Hirschman saw substantial intellectual risks in imposing simplistic order over the variegated forms of real life, and instead strove to create petite idées that could be linked together. Hirschman saw parallels with Christopher Alexander's (1964) work in design theory - an important early influence on complexity - in which identifying 'isolable subsystems' of relative order to address can be the basis for linking small efforts towards a larger goal (Hirschman, 1967, pp. 24, FN 12). However, Hirschman understood that while the simplicity of a model makes it wrong, the absence of simplicity makes ideas unusable. The flexibility of Hirschman's intellectual scaffolding of petite idées in Development Projects Observed was poorly received by the World Bank despite their having commissioned the study (Adelman, 2013), and the imperative of imposing a bureaucratically legible order over the messy vitality of lived experience still impedes the work of development actors.

Andrew Natsios (2010) has written compellingly of USAID's operations, in which the growing use of private consultants has been matched by a 'counter-bureaucracy' whose job it is to monitor and assess the bureaucracy and their projects. There is an onerous burden of reporting to fulfil the surveillance needs of the counter-bureaucracy. Navigating the reporting requirements in such a way that allows a project to function without deviating from its terms of reference or finance rules is a task best suited to accountants and lawyers, and Natsios bemoans the demise of the development professional within this context as they cannot survive.

The structure of the interventions themselves produces these negative outcomes. As terms of reference for consultants are written, a pre-approved field of for-profit contractors will assemble the 
resumes of likely personnel whose chief attribute will be related experience elsewhere, i.e. technical expertise. That isomorphic mimicry is a pathological feature of development assistance is driven by the leading role of international consultants in the donor funded technical assistance exercises which define the objectives and approach to institutional reforms. The assembled consultants bring non-local knowledge, and the terms of their hiring bind them tightly to a project written without deep knowledge of the local situation. Adapting to the local situation has to be carefully considered within the scope of the project documents so as not to alert the counter-bureaucracy, and development practitioners may have to work against the counter-bureaucracy by excluding their successful strategies from internal reporting (Eyben, 2010). For USAID projects in Pakistan, monitoring was supplemented by congressional requests for information as representatives were on high alert for the prospect of spotlighting the waste of taxpayer money on an ally with whom the US had a troubled relationship.

The US-Pakistan relationship shaped when development projects were started and how long the projects continued. The USAID-funded work which produced the 1992 strategy paper ended due to the Pressler amendment, sanctioning Pakistan for its pursuit of nuclear weapons. The Pakistani perspective is that the US conveniently overlooked that program so long as the war in Afghanistan meant that Pakistan was an important ally. While DFID has moved in the opposite direction of distancing development interventions from politics, the US moved USAID under the purview of the Department of State, thereby cementing the instrumental status of development assistance as a diplomatic tool. The Centre for Global Development suggests that USAID's overt politicisation has worked against its development interventions (Birdsall, Elhai, \& Kinder, 2010).

Two complications raised by the political backdrop to USAID's activities in Pakistan result from the extra scrutiny triggered by its high profile and the need to rapidly produce results to justify the expense. The amount of total aid and the context of the ongoing conflict attracted the attention of congressional representatives. In effect, this provoked the counter-bureaucracy to a heightened level 
surveillance which detracts from the time and energy available to actually work on the project.iii Every development assistance project must work within a constrained timetable. Each project must spend money - the burn rate - in order to justify its existence. The pressure to spend money quickly conflicts with any inclination to take the time to assess the local situation, thus heightening the appeal of best practices from overseas with which the internationally sourced technical experts are familiar. Isomorphic mimicry is thus promoted by the time limitations of the development assistance project, not as a strategy to make states look legitimate but as a way for contractors to make development projects look legitimate under the pressures of time.

In their criticism of the World Bank proposed reform program for electrical power sectors everywhere, Electricité de France highlighted how the spirit of public service was being abandoned. Peter Evans' (1995) seminal formulation of embedded autonomy draws on the importance of state bureaucracy which reinforces its capabilities through esprit-de-corps and other non-contractual forms of contract (Rueschemeyer \& Evans, 1985). Instead, power sector governance reforms have emphasized purely contractual relationships in their attempts to improve governance. The doctrine of new public management has been as unsuccessful in developed countries as developing (Hood \& Dixon, 2015). The increase in transaction costs noted in the Electricité de France roundtable with the World Bank has outweighed any increases in efficiency and the spirit of public service has been a casualty in this process. The tools of development assistance reflect this same paradigm whereby bureaucracies such as USAID have had their permanent staff reduced at the expense of using contractors and sub-contractors.

That USAID was in danger of repeating past failures when it greatly expanded aid to Pakistan after 2009 was highlighted in two research papers produced by the Centre for Global Development. In a review of the World Bank and partners' support for social spending in the 1990s, Birdsall et al. (2005) observe that, despite monitoring reports indicating poor performance of the programs, the World Bank chose to continue the program and not impose the specified penalties for the Pakistan government's 
failure to meet its commitments to reform. The donor bias to disbursement trumped concerns over performance, expectations were unrealistic, and more funding didn't translate to leverage in the face of local power relations and the underlying political economy. An analysis of past assistance to the energy sector was described by Kinder and Elhai (2010) as 'an exercise in déjà vu,' with donors pushing for the same package of reforms and being similarly disappointed from 1992 onwards. On the basis of their research, the Centre for Global Development wrote open letters to Ambassador Holbrooke (heading the USAID effort to Pakistan at the time) outlining their findings. Despite arguing that this same approach had failed in the past when pushed by the World Bank and Asian Development Bank, Birdsall (2010) advocates that USAID condition its support for the energy sector on the achievement of pricing reforms and institutions to support private investment. Local power relations and political economy do not feature in the recommendations. If this evidence wasn't sufficient to argue against more of the same programming, then there's little scope to suggest that a development actor can ever choose against providing development assistance that is politically desired.

\section{Conclusion}

The case of the Pakistani power sector and its experience with governance reforms reveals how development actors revisit the same reform programs despite acknowledging their past failures. Awareness of the unsuitability of a reform program can be present before, during, and after the intervention, but future programming won't necessarily adapt in response. Governance reform is difficult enough, but the tools of development programming themselves are a higher order obstacle to reform over and above the substantive challenges. The pathologies of development practice are borne by the tools themselves, and interfere with the ability to bring local knowledge to the problem, adapt based on experience, or take a long-term perspective rather focus on quick wins. The 1992 privatization strategy insisted that achieving commercial performance standards was a necessary first step to 
introducing private actors into the power sector. Specifically, the goal of inviting new investment without sovereign guarantees depended on it. The private investment that took place relied on sovereign guarantees, thus undermining a key goal of introducing private power producers.

The inability of development actors to respond when shortcomings in the programme appear bodes ill for any approach which relies on rapid reassessments of development programming and responses. While an adaptive and flexible approach might be intellectually compelling, it doesn't match the experience of how development actors work in practice. Moreover, the contracts through which external consultants - an increasingly large component of development assistance - are engaged are ill suited to opportunistic responses or the acknowledgement of failures. The counter-bureaucracy which handles contractual oversight acts against the adaptive and iterative approach that is being called for. When development programs begin and end for reasons of state then the potential to take an experimental orientation to an adaptive search for successful innovation is reduced. The need to declare quick successes is increased when development programs are under a political spotlight.

The recent wave of reformed approaches to development take on board these past shortcomings and offer intellectually compelling alternatives. The proponents of this most recent wave, however, acknowledge how higher level obstacles block the way to reforming development itself. Booth and Unsworth (2014) conclude their case for locally led politically smart development by ways in which the recruitment and staffing of their own organizations would have to change in order to adopt this approach. They don't say how this would be achieved, and one is left with the impression that this is a truly daunting task that is unlikely to be achieved. Chapter 10 of Andrews' book applies the PDIA logic to "reforming the rules of the development game itself" and concludes that "It seems like the actors involved in authorizing and negotiating development interventions are satisfied with the status quo" (Andrews, 2013, p. 231). Practitioners might continue to 'subvert the current system' rather than 
expend the effort to reform the development actors themselves, but none of these discussions involve the recipients and supposed beneficiaries of aid (Green, 2014).

The satisfaction of the actors structuring development interventions with the status quo is indicative of how development practices are systematically disembedded - in a Polanyian sense (Polanyi, 2001) - from development outcomes. This paper has argued that a higher order of obstacles impedes the feedback loops between decision-making around development practices and outcomes as experienced in local contexts. The move to take a more adaptive approach to development interventions is surely more promising than a less adaptive approach, but - just as with prior approaches - its prospects for success will be undermined by the structure of development projects, the reliance on external contractors, the monitoring and oversight of the counter-bureaucracy, and the primacy of the donor's political objectives. By identifying where isomorphic mimicry is at its most coercive, development actors can pinpoint where the 'looking like a state' phenomena is most likely to appear. In these situations the state is likely to decouple the actual functions of its institutions from the organizational form. If a development actor cannot or will not back away from such an intervention, it indicates that the local feedback loops which inform effective policy-making have been severed and that the beneficiary of the project is no longer the local population. In recognizing the way that higher level obstacles limit the possibility of doing development better (or differently), the avoidance of those obstacles will expand the space for improved development outcomes. 
Published in Journal of Development Studies

http://dx.doi.org/10.1080/00220388.2016.1146704

\section{Acknowledgements}

Insightful comments and advice were provided by Mian Shahid Ahmed, Munir Ahmed, Charles Kurzman, Salahuddin Rifai, and the members of the SMU Academic Writing Group. This research was supported by the Singapore Ministry of Education Academic Research Fund Tier 1 grant [C242/MSS12S008].

\footnotetext{
' Interview with Mian Shahid Ahmed. Field notes June 142011.

ii Interview with an employee of an international financial institution involved in the preparation of the FODP report. Field notes September 82011.

iii In my own capacity as a USAID contractor I handled requests for such reports and the need to produce success stories at regular intervals.
} 
Published in Journal of Development Studies

http://dx.doi.org/10.1080/00220388.2016.1146704

\section{References}

Adelman, J. (2013). Worldly Philosopher: The Odyssey of Albert O. Hirschman. Princeton, NJ: Princeton University Press.

Alexander, C. (1964). Notes on the Synthesis of Form. Cambridge, MA: Harvard University Press.

Andrews, M. (2013). The limits of institutional reform in development : changing rules for realistic solutions. Cambridge: Cambridge University Press.

Arthur, W. B. (1990). Positive Feedbacks in the Economy. Scientific American, 262(2), 92-99.

Axelrod, R. M. (1997). The complexity of cooperation : agent-based models of competition and collaboration. Princeton, NJ: Princeton University Press.

Birdsall, N. (2010). U.S. Development Assistance to Pakistan's Energy Sector (Third open letter to Ambassador Richard Holbrooke). Washington, DC.

Birdsall, N., Elhai, W., \& Kinder, M. (2010). Beyond Bullets and Bombs: Fixing the U.S. Approach to Development in Pakistan. Washington, DC.

Birdsall, N., Malik, A., \& Vaishnav, M. (2005). Poverty and the Social Sectors: The World Bank in Pakistan 1990-2003. Washington, DC.

Booth, D., \& Unsworth, S. (2014). Politically smart, locally led development. London.

Colander, D. C., \& Kupers, R. (2014). Complexity and the Art of Public Policy: Solving Society's Problems from the Bottom Up. Princeton, NJ: Princeton University Press.

DiMaggio, P. J., \& Powell, W. W. (1983). The Iron Cage Revisited - Institutional Isomorphism and Collective Rationality in Organizational Fields. American Sociological Review, 48(2), 147-160. doi: Doi 10.2307/2095101

Disch, A., Vigeland, E., \& Sundet, G. (2009). Anti-corruption Approaches: A Literature Review. Oslo.

Dobbin, F. (1994). Forging Industrial Policy: The United States, Britain, and France in the railway age. New York: Cambridge University Press.

Evans, P. (1995). Embedded Autonomy: States and Industrial Transformation. Princeton, NJ: Princeton University Press.

Eyben, R. (2010). Hiding Relations: The Irony of 'Effective Aid'. European Journal of Development Research, 22(3), 382-397.

Fraser, J. (2005). Lessons from the Independent Private Power Experience in Pakistan Energy and Mining Sector Board Discussion Paper. Washington, DC.

Friends of Democratic Pakistan. (2010). Integrated Energy Sector Recovery Report \& Plan.

Glen, J. (1992). Private Sector Electricity in Developing Countries: Supply and Demand Discussion Paper Number 15. Washington, DC.

Government of Pakistan. (1994). Report of Prime Minister's Task Force on Energy. Islamabad.

Govt agencies to manage flood aid, donors told. (2010). Dawn. Retrieved from http://www.dawn.com/news/853909/govt-agencies-to-manage-flood-aid-donors-told

Green, D. (2014). Thinking and Working Politically update: where have aid agencies, consultants etc got to?

Hirschman, A. O. (1967). Development Projects Observed. Washington, DC: Brookings Institution.

Holland, J. (1992). Complex Adaptive Systems. Daedalus, 121(1), 17-30.

Hood, C., \& Dixon, R. (2015). A government that worked better and cost less? : evaluating three decades of reform and change in UK central government. Oxford: Oxford University Press.

Institute of Development Studies. (2010). An Upside-down View of Governance. Brighton.

International Resources Group, Putnam Hayes \& Bartlett, \& Hunton \& Williams. (1992). WAPDA's

Strategic Plan for the Privatization of the Pakistan Power Sector (Prepared for USAID/

Islamabad). Islamabad. 
Jervis, R. (1997). System effects : complexity in political and social life. Princeton, NJ: Princeton University Press.

Kale, S. (2004). Current Reforms: The Politics of Policy Change in India's Electricity Sector. Pacific Affairs, 77(3), 467-491.

Kiani, K. (2014). IPPs suspend notices calling sovereign guarantees, Dawn. Retrieved from http://www.dawn.com/news/1150322

Kinder, M., \& Elhai, W. (2010). Pakistan's Energy Sector: Groundhog Day for USA? Washington, DC.

Krause, P. (2013). Of institutions and butterflies: is isomorphism in developing countries necessarily a bad thing? London.

Kurtz, C. F., \& Snowden, D. J. (2003). The new dynamics of strategy: Sense-making in a complex and complicated world. Ibm Systems Journal, 42(3), 462-483.

Meyer, J., \& Rowan, B. (1977). Institutional Organizations: Formal Structure as Myth and Ceremony. American Journal of Sociology, 83, 340-363.

Miller, J. H., \& Page, S. E. (2007). Complex adaptive systems : an introduction to computational models of social life. Princeton, N.J.: Princeton University Press.

Ministry of Water and Power. (1997). Report of the Committee Constituted by the Ministry of Water and Power for Corporatization of WAPDA (Power Wing). Islamabad, Pakistan.

Mitchell, M. (2009). Complexity : a guided tour. New York: Oxford University Press.

Natsios, A. (2010). The Clash of the Counter-bureaucracy and Development. Washington, DC.

Polanyi, K. (2001). The great transformation : the political and economic origins of our time. Boston, MA: Beacon Press.

Pritchett, L., \& Woolcock, M. (2004). Solutions when the solution is the problem: Arraying the disarray in development. World Development, 32(2), 191-212. doi: DOI 10.1016/j.worlddev.2003.08.009

Pritchett, L., Woolcock, M., \& Andrews, M. (2013). Looking Like a State: Techniques of Persistent Failure in State Capability for Implementation. Journal of Development Studies, 49(1), 1-18. doi: 10.1080/00220388.2012.709614

Private Power and Infrastructure Board. (2001). Status Report: Power Policy, 1994. Islamabad, Pakistan: Ministry of Water and Power, Government of Pakistan.

Ramalingam, B. (2013). Aid on the edge of chaos : rethinking international cooperation in a complex world. Oxford: Oxford University Press.

Rana, S. (2012). Power sector dues: Govt defaults on sovereign guarantees Express Tribune. Retrieved from http://tribune.com.pk/story/376152/power-sector-dues-govt-defaults-on-sovereignguarantees/

Rifai, S. (2009, Jan-March). Economic Despatch in National Transmission and Despatch Company (NTDC) - Pakistan. Electronic Forum, 5.

Rueschemeyer, D., \& Evans, P. (1985). The state and economic transformation: toward an analysis of the conditions underlying effective intervention. In P. Evans, T. Skocpol \& D. Rueschemeyer (Eds.), Bringing the State Back In (pp. 44-76). Cambridge: Cambridge University Press.

United States Agency for International Development. (2010). Terms of Reference: Pakistan Power Distribution Companies (DISCOs) Performance Improvement Program.

United States Agency for International Development. (2014). Local Systems: A Framework for Supporting Sustained Development. Washington, DC.

Victor, D. G., \& Heller, T. C. (2007). The political economy of power sector reform : the experiences of five major developing countries. New York: Cambridge University Press.

Wells, L. T., \& Ahmad, R. (2007). Making foreign investment safe : property rights and national sovereignty. Oxford: Oxford University Press.

Williams, J. H., \& Dubash, N. K. (2004). Asian electricity reform in historical perspective. Pacific Affairs, 77(3), 411-436. 
Williams, J. H., \& Ghanadan, R. (2006). Electricity reform in developing and transition countries: A reappraisal. Energy, 31(6-7), 815-844.

Woodhouse, E. (2006). The Obsolescing Bargain Redux: Foreign Investment in the Electric Power Sector in Developing Countries. N.Y.U. Journal of International Law and Politics, 38, 121-246.

World Bank. (1993). Power Supply in Developing Countries: Will Reform Work. Proceedings of a Roundtable Co-Sponsored by the World Bank and Electricité de France. Washington, DC: World Bank.

World Bank. (2001). Implementation Completion Report (03370; 29820) On a Loan in the Amount of US\$150 Million to the Islamic Republic of Pakistan for a Private Sector Energy Development Project. Washington, DC.

World Bank. (2008). Public Sector Reform: What Works and Why? Washington DC. 